\title{
Systolic time intervals in measurement of inotropic response to drugs
}

\author{
B F JOHNSON*, M K MEERAN, A FRANK, S H TAYLOR \\ From the Department of Medicine, General Infirmary, Leeds; and Wellcome Research Laboratories, Beckenham,Kent
}

SUMMARY During periods of tachycardia induced by atrial pacing in eight patients, moderate increments in $\mathrm{dP} / \mathrm{dt}(\max )$ and $(\mathrm{dP} / \mathrm{dt}) / \mathrm{CPIP}$ (common produced intraventricular pressure) and moderate reductions in left ventricular ejection time (LVET) and $\mathrm{Q}-\mathrm{S}_{2}$ were demonstrated. These changes varied between individuals, but reduction in systolic intervals was consistently less than that reported from populations showing a range of resting heart rates. Individual regression formulae relating each variable to paced heart rate were used to calculate rate-dependent and rate-independent changes induced by isoprenaline and ouabain. Despite technical difficulty in precise measurement of systolic intervals, there was an excellent inverse correlation between rate-independent changes in $\mathrm{Q}-\mathrm{S}_{2}$ and in both $\mathrm{dP} / \mathrm{dt}(\max )$ and $(\mathrm{dP} / \mathrm{dt}) / \mathrm{CPIP}$. Rate-independent change in $\mathrm{Q}-\mathrm{S}_{2}$ appears to be a practical, moderately sensitive, and reasonably precise measure of the inotropic effect of a drug which does not radically alter left ventricular end-diastolic pressure or blood pressure: Day-to-day variation in systolic intervals may limit the use of the technique to studies of short duration.

Determination of the inotropic activity of a drug essentially belongs to the animal laboratory, but confirmation of this activity, and particularly characterisation of its dose-response effects in man, is a necessary prelude to its rational clinical employment. Direct measurement of changes in contractile activity and pumping function of the left ventricle presently furnish the most accurate indication of alterations in inotropic activity. ${ }^{1-3}$ Cardiac catheterisation, however, is cumbersome, limited by ethical considerations, and often of such brevity as to preclude the measurement of duration of activity of a drug or its dose-response effects. Non-invasive methods have therefore been sought as a means of making repeated measurements of left ventricular activity; among such methods measurement of the duration of the various components of systole has been the most widely acclaimed. ${ }^{4-6}$ The utility of these methods, however, in evaluating changes in left ventricular activity induced by drugs has yet to be fully tested. It was the purpose of this study, therefore, to evaluate the precision by which measurements of non-invasive systolic time intervals

* Present address: Division of Clinical Pharmacology, University of Massachusetts. Medical Center, Worcester, Massachusetts 01605, USA

Received for publication 5 June 1981 reflect changes in intraventricular pressure before and after the administration of drugs known to increase inotropic activity.

\section{Subjects and methods}

Four normal subjects (aged 20 to 35 years), and six male and two female patients (aged 23 to 45 years) admitted for the investigation of chest pain were studied. All were in sinus rhythm. In the patients, radiographic cardiac silhouette was normal. Electrocardiograms at rest and during treadmill exercise up to heart rates of 160 beats per minute were normal in all. Left ventricular end-diastolic pressure during supine leg exercise did not exceed $25 \mathrm{mmHg}$. None was receiving drugs at the time of the study. Informed consent was obtained from all patients. ${ }^{78}$

\section{DESIGN OF INVESTIGATION}

The four normal subjects were used to determine the day-to-day variation in systolic time intervals. Measurements were made on separate days at the same time each morning two hours after a light breakfast without tea or coffee and after they had been quietly reclining for 20 minutes.

Patients were studied resting supine without sedation two hours after a light meal. Left ventricular 
catheterisation was performed by the percutaneous Seldinger technique via the right brachial artery using a $(55 \times 0.1 \mathrm{~cm})$ red Portex nylon catheter with a frequency response of $40 \mathrm{~Hz}$. Pressure was transduced by a strain-gauge manometer (SEM 482), the output being recorded on a multichannel ultraviolet recorder (SEM 3012). The common zero reference level for all pressures was set at $10 \mathrm{~cm}$ below the sternal angle and calibrated over the range 0 to $100 \mathrm{mmHg}$. Linearity of the manometers was checked before each study, and zero and calibration checks were made before and after each period of study. The left ventricular catheter was intermittently flushed from a reservoir with heparinised saline. The first derivative of left ventricular pressure $(\mathrm{dP} / \mathrm{dt})$ was computed continuously with an $\mathrm{R}-\mathrm{C}$ differentiating circuit with a time constant of $4.7 \times 10^{-3} \mathrm{mmHg} / \mathrm{cm}$ per s. A bipolar pacing catheter (USCI 5F United States Catheter Co.) was introduced through a right brachial vein and positioned at the junction of the superior vena cava and right atrium. Simultaneously with left ventricular pressure measurements, recordings were made of the electrocardiogram, phonocardiogram, and carotid arterial pulsations at a paper speed of $100 \mathrm{~mm} / \mathrm{second}$.

The electrocardiogram was recorded from adhesive-disc electrodes applied to each shoulder, the lower rib-cage, and the $V_{5}$ position, calibrated externally $(1 \mathrm{~mm}=0.1 \mathrm{mV})$, and recorded on an ultraviolet recorder (SE Laboratories Model 3012). Lead II was employed for systolic time interval measurements.

A microphone (Siemen-Elema AB, Stockholm) was placed over the upper praecordium in the best position for recording the initial high frequency vibrations of the first and second heart sounds and connected to a preamplifier (SEM 4902). Recordings were made in a frequency band of 100 to $500 \mathrm{~Hz}$.

The carotid arterial pulsation was recorded with a Philips Displacement Pick-Up 9310, which measured static and dynamic relative displacements, and connected to a Philips PT 1200 amplifier with a time constant of $1.0 \mathrm{~s}$ and a frequency range set at 0-100 Hz. Recordings were made with the head tilted towards the contralateral shoulder.

The obligatory requirements for recordings were a steady electrocardiographic baseline, sharp inscription of the initial vibrations of the first and second heart sounds, a sharp upstroke and clear incisural notch on the carotid arterial pulse tracing, and a clear atrial component of the left ventricular pressure measurements.

Studies were made at rest; control measurements were obtained after the patient had been lying quietly for 20 minutes. Atrial pacing was then started at increments of approximately 10 beats per minute to achieve a maximum of 140 to 160 beats per minute; pacing was discontinued with the appearance of any type of ectopic activity. Ten minutes later, isoprenaline was infused by means of a Harvard electromechanical pump (Model 901) in increments of $1 \mu \mathrm{g} /$ minute every two minutes up to a maximum of $16 \mu \mathrm{g} /$ minute (maximum heart rate 146 beats per minute). Twenty minutes later, $0.75 \mathrm{mg}$ ouabain was given intravenously and measurements repeated at one, five, 10, 25, and 45 minutes.

\section{LABORATORY TECHNIQUES, MEASUREMENTS, AND STATISTICAL ANALYSIS}

\section{Invasive techniques}

First derivative of left ventricular systolic pressure $(\mathrm{dP} / \mathrm{dt}$ ) was calibrated in units of $\mathrm{mmHg} / \mathrm{s}$ using a sinusoidal input. Measurements of the peak value, or $\mathrm{dP} / \mathrm{dt}(\mathrm{max})$, were determined as the average of values recorded over 10 beats. Further, the instant in each cycle at which the intraventricular pressure exceeded end-diastolic pressure by $40 \mathrm{mmHg}$ was determined. Hence, the common produced intraventricular pressure was $40 \mathrm{mmHg}$ in every cycle. This determined level of intraventricular pressure was consistently below aortic diastolic pressure throughout each experiment. Average values of $\mathrm{dP} / \mathrm{dt}$ recorded at this intraventricular pressure were again derived from 10 consecutive beats, and the ratio (dP/dt)/CPIP calculated at $\mathrm{dP} / \mathrm{dt}$ divided by $40 \mathrm{mmHg}$. The ventricular end-diastolic pressure was measured at the nadir of the ventricular pressure recording after the atrial systolic increment.

\section{Non-invasive techniques}

The $Q-S_{2}$ interval (duration of electromechanical systole) was measured from the onset of ventricular depolarisation ( $Q$ wave) to the first high frequency vibration of the aortic component of the second heart sound. Left ventricular ejection time was measured from the beginning of the rapid upstroke to the trough of the incisural notch of the carotid arterial pulse tracing. Pre-ejection period was calculated by subtraction of left ventricular ejection time from Q- $S_{2}$ : this interval corresponds with the beginning of ventricular depolarisation to the start of left ventricular ejection.

From the photographic records, time intervals were determined in milliseconds with the assistance of a D-MAC computer linkage, programmed to derive and print out heart rate, individual intervals, and their mean \pm standard error for each selected series of heart beats. Series of 15 to 20 consecutive beats were selected, as it was found that a minimum of 12 individual beats was required before the observed mean value changed less than $3 \%$ with the addition of a further beat. Systolic time indices corrected for 
heart rate ${ }^{9}$ were also derived, but were not analysed in detail for reasons explained later.

\section{Results}

VARIATION IN SYSTOLIC TIME INTERVALS IN NORMAL SUBJECTS (Table 1)

In all four normal subjects there was considerable day-by-day variation in heart rate and systolic time intervals, despite the fact that they were entirely familiar with the procedure and that the measurements were made at the same time each day and under identical laboratory conditions. Moreover, there was little within-subject correspondence between changes in heart rate and duration of electromechanical systole $\left(\mathrm{Q}-\mathrm{S}_{2}\right)$, ejection phase, or pre-ejection time. There was an inverted relation between changes in heart rate and directional changes in systolic time intervals at some point in each subject.

Table 1 Within-subject variation in uncorrected systolic intervals recorded at 09.30 am on separate days

\begin{tabular}{llllr}
\hline Subject & Heart rate & $Q S_{2}$ & LVET & PEP \\
\hline H & 70 & 394 & 302 & 92 \\
& 46 & 432 & 318 & 114 \\
& 63 & 432 & 322 & 110 \\
F & 72 & 374 & 283 & 91 \\
& 73 & 387 & 298 & 89 \\
& 61 & 389 & 299 & 90 \\
& 63 & 423 & 324 & 99 \\
& & & & \\
M & 56 & 393 & 326 & 67 \\
& 53 & 422 & 341 & 81 \\
& 65 & 398 & 306 & 92 \\
P & 68 & 393 & 290 & 103 \\
& 68 & 395 & 301 & 94 \\
& 72 & 369 & 294 & 75 \\
& 75 & 370 & 295 & 75 \\
\hline
\end{tabular}

CORRELATION BETWEEN DIRECT AND NONINVASIVE METHODS OF MEASUREMENT OF RATE OF RISE OF LEFT VENTRICULAR PRESSURE DURING SYSTOLE IN PATIENTS

Control values

At rest, $\mathrm{dP} / \mathrm{dt}(\max )$ and $(\mathrm{dP} / \mathrm{dt}) / \mathrm{CPIP}$ averaged $1219 \pm 121 \mathrm{mmHg} / \mathrm{s}$ and $25 \pm 2 \cdot 1 \mathrm{~s}$, respectively.

Neither variable showed any between-subject relation to heart rate (range 71 to 90 beats $/ \mathrm{min}$ ). Left ventricular end-diastolic pressure was $11 \pm 1.5$ $\mathrm{mmHg}$. Simultaneous measurements of $\mathrm{Q}-\mathrm{S}_{2}$, left ventricular ejection time, and pre-ejection period were $380 \pm 5,284 \pm 5$, and $96 \pm 5 \mathrm{~ms}$, respectively.

Atrial pacing (Table 2)

During atrial pacing there was a tendency to reduction in left ventricular end-diastolic pressure and a stepwise increase in $\mathrm{dP} / \mathrm{dt}(\max )$ and $(\mathrm{dP} / \mathrm{dt}) / \mathrm{CPIP}$ in almost all subjects. There was a predictable linear relation between the increase in paced heart rate and both of the latter measurements (Fig. 1 and 2).

$\mathrm{Q}-\mathrm{S}_{2}$ and left ventricular ejection time were both consistently reduced in all subjects with increase in paced heart rate, and there was a predictable linear relation between heart rate increment and both

Table 2 Changes during atrial pacing

\begin{tabular}{|c|c|c|c|c|c|c|c|}
\hline $\begin{array}{l}\text { Case } \\
\text { No. }\end{array}$ & Rate & $L V E D P$ & $\begin{array}{l}d P / \\
d t(\max )\end{array}$ & $\begin{array}{l}(d P / d t) / \\
C P I P\end{array}$ & $Q-S_{2}$ & LVET & PEP \\
\hline 1 & $\begin{array}{r}66 \\
99 \\
107 \\
115\end{array}$ & & & & $\begin{array}{l}384 \\
339 \\
330 \\
328\end{array}$ & $\begin{array}{l}286 \\
239 \\
228 \\
207\end{array}$ & $\begin{array}{r}98 \\
100 \\
102 \\
121\end{array}$ \\
\hline 2 & $\begin{array}{r}81 \\
102 \\
106 \\
123 \\
130\end{array}$ & $\begin{array}{l}16 \\
16 \\
14 \\
14 \\
12\end{array}$ & $\begin{array}{l}1299 \\
1477 \\
1460 \\
1831 \\
1801\end{array}$ & $\begin{array}{l}28 \cdot 9 \\
29 \cdot 3 \\
31 \cdot 2 \\
34 \cdot 3 \\
37 \cdot 5\end{array}$ & $\begin{array}{l}344 \\
328 \\
326 \\
287 \\
284\end{array}$ & $\begin{array}{l}267 \\
242 \\
237 \\
212 \\
204\end{array}$ & $\begin{array}{l}73 \\
87 \\
89 \\
75 \\
80\end{array}$ \\
\hline 3 & $\begin{array}{r}78 \\
88 \\
122 \\
134\end{array}$ & $\begin{array}{l}12 \\
13 \\
12 \\
12\end{array}$ & $\begin{array}{l}1035 \\
1222 \\
1428 \\
1460\end{array}$ & $\begin{array}{l}20 \cdot 4 \\
21 \cdot 1 \\
25 \cdot 0 \\
27 \cdot 6\end{array}$ & $\begin{array}{l}381 \\
358 \\
313 \\
302\end{array}$ & $\begin{array}{l}306 \\
273 \\
233 \\
216\end{array}$ & $\begin{array}{l}75 \\
85 \\
80 \\
86\end{array}$ \\
\hline 4 & $\begin{array}{r}72 \\
96 \\
122 \\
140\end{array}$ & $\begin{array}{l}16 \\
14 \\
12 \\
12\end{array}$ & $\begin{array}{r}880 \\
1260 \\
1642 \\
1908\end{array}$ & $\begin{array}{l}24 \cdot 1 \\
28 \cdot 8 \\
36 \cdot 0 \\
41 \cdot 5\end{array}$ & $\begin{array}{l}394 \\
365 \\
338 \\
315\end{array}$ & $\begin{array}{l}291 \\
264 \\
234 \\
213\end{array}$ & $\begin{array}{l}103 \\
101 \\
104 \\
102\end{array}$ \\
\hline 5 & $\begin{array}{r}77 \\
86 \\
99 \\
109 \\
123 \\
132 \\
141 \\
161\end{array}$ & $\begin{array}{l}8 \\
7 \\
8 \\
4 \\
4 \\
4 \\
4 \\
4\end{array}$ & $\begin{array}{r}836 \\
906 \\
1009 \\
1260 \\
1269 \\
1052 \\
1113 \\
1571\end{array}$ & $\begin{array}{l}16 \cdot 0 \\
16 \cdot 8 \\
18 \cdot 7 \\
22 \cdot 4 \\
20 \cdot 6 \\
19 \cdot 6 \\
24 \cdot 7 \\
31.0\end{array}$ & $\begin{array}{l}378 \\
371 \\
357 \\
354 \\
326 \\
320 \\
314 \\
294\end{array}$ & $\begin{array}{l}266 \\
264 \\
250 \\
251 \\
226 \\
217 \\
214 \\
190\end{array}$ & $\begin{array}{l}112 \\
106 \\
107 \\
103 \\
100 \\
103 \\
100 \\
104\end{array}$ \\
\hline 6 & $\begin{array}{r}86 \\
91 \\
98 \\
114 \\
123 \\
133 \\
145 \\
149\end{array}$ & $\begin{array}{r}7 \\
4 \\
6 \\
4 \\
9 \\
-4 \\
-\end{array}$ & $\begin{array}{l}1413 \\
1700 \\
1860 \\
1573 \\
2950 \\
3106 \\
3200 \\
3000\end{array}$ & $\begin{array}{l}23 \cdot 9 \\
29 \cdot 5 \\
38 \cdot 2 \\
40 \cdot 5 \\
52 \cdot 4 \\
54 \cdot 5 \\
54 \cdot 6 \\
-\end{array}$ & $\begin{array}{l}398 \\
373 \\
374 \\
339 \\
324 \\
313 \\
300 \\
291\end{array}$ & $\begin{array}{l}281 \\
270 \\
263 \\
241 \\
226 \\
214 \\
193 \\
183\end{array}$ & $\begin{array}{r}117 \\
103 \\
111 \\
98 \\
98 \\
99 \\
107 \\
108\end{array}$ \\
\hline 7 & $\begin{array}{r}62 \\
87 \\
91 \\
114 \\
125 \\
131 \\
141\end{array}$ & $\begin{array}{l}8 \\
6 \\
5 \\
4 \\
4 \\
3 \\
-\end{array}$ & $\begin{array}{l}1462 \\
1672 \\
1761 \\
1920 \\
1922 \\
2039 \\
-\end{array}$ & $\begin{array}{l}29 \cdot 3 \\
29 \cdot 0 \\
29 \cdot 4 \\
30 \cdot 3 \\
32 \cdot 0 \\
30 \cdot 7 \\
-\end{array}$ & $\begin{array}{l}413 \\
360 \\
361 \\
333 \\
324 \\
315 \\
314\end{array}$ & $\begin{array}{l}306 \\
265 \\
262 \\
242 \\
234 \\
225 \\
205\end{array}$ & $\begin{array}{r}107 \\
95 \\
99 \\
90 \\
91 \\
91 \\
110\end{array}$ \\
\hline 8 & $\begin{array}{r}76 \\
82 \\
94 \\
106 \\
109\end{array}$ & $\begin{array}{l}12 \\
12 \\
10 \\
10 \\
10\end{array}$ & $\begin{array}{l}1613 \\
1857 \\
2035 \\
2228 \\
2315\end{array}$ & $\begin{array}{l}32 \cdot 1 \\
36 \cdot 3 \\
38 \cdot 0 \\
42 \cdot 5 \\
44 \cdot 0\end{array}$ & $\begin{array}{l}387 \\
375 \\
365 \\
341 \\
340\end{array}$ & $\begin{array}{l}311 \\
305 \\
295 \\
274 \\
268\end{array}$ & $\begin{array}{l}75 \\
70 \\
70 \\
67 \\
72\end{array}$ \\
\hline
\end{tabular}




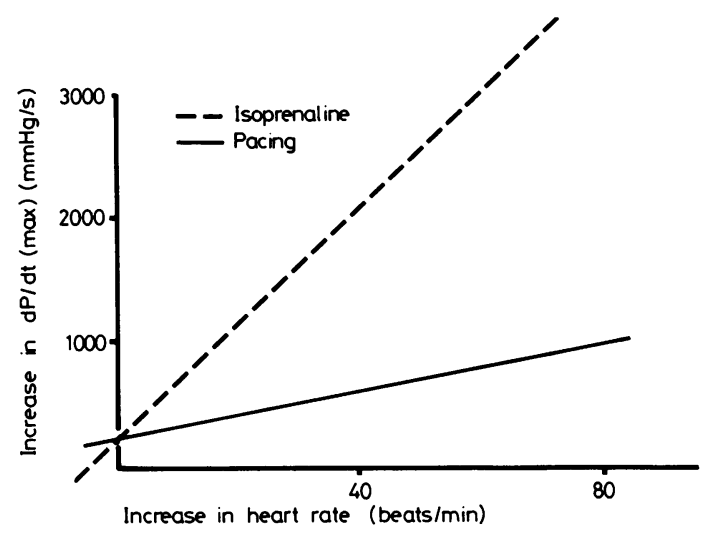

Fig. 1 Comparison of group regression lines relating increases in $d P / d t(\max )$ and heart rate during atrial pacing and isoprenaline infusion.

variables (Fig. 3 and 4). There was no consistent change in pre-ejection period in any of the eight subjects during pacing increase in heart rate (Fig. 5).

Isoprenaline infusion (Table 3)

Infusion of isoprenaline was associated with increases in heart rate of 41 to 65 beats per minute in six subjects, but in two others the maximal heart rate increases were 9 and 17 beats/min despite an infusion rate of $12 \mu \mathrm{g} / \mathrm{min}$. In all subjects there was a consistent stepwise reduction in left ventricular enddiastolic pressure together with a stepwise increase in $\mathrm{dP} / \mathrm{dt}(\max )$ and $(\mathrm{dP} / \mathrm{dt}) / \mathrm{CPIP}$. There was a significant linear relation between the increase in heart rate and both of the latter measurements, the changes after isoprenaline being significantly greater

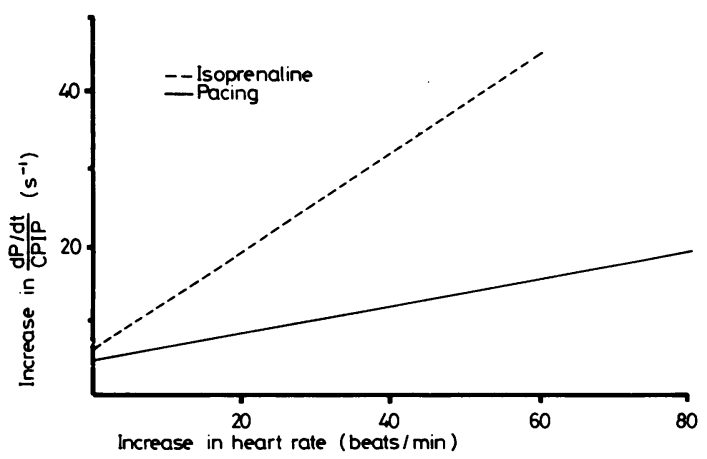

Fig. 2 Comparison of group regression lines relating increases in $(d P / d t) / C P I P$ and heart rate during atrial pacing and isoprenaline infusion.

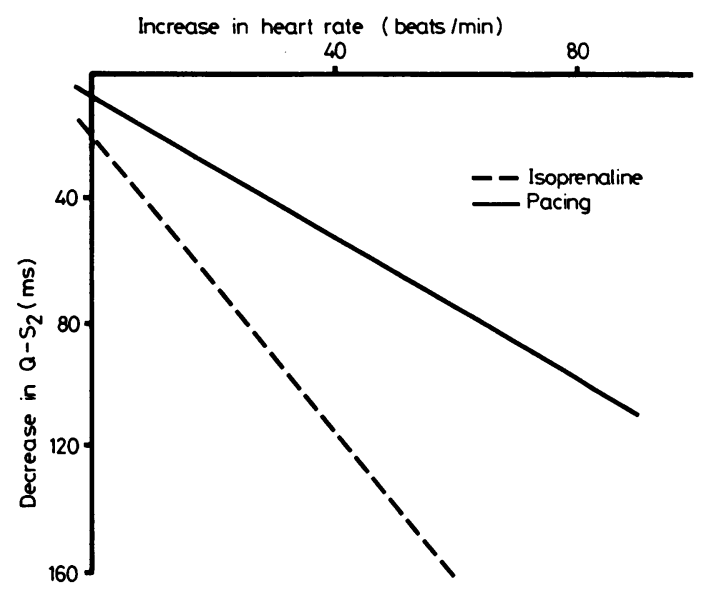

Fig 3 Comparison of group regression lines relating decrease in $Q S_{2}$ with increase in heart rate during atrial pacing and isoprenaline infusion.

than those associated with pacing-induced increases in heart rate (Fig. 1 and 2).

Likewise the reductions in $\mathrm{Q}-\mathrm{S}_{2}$, left ventricular ejection time, and pre-ejection period at given increases in heart rate were significantly greater after isoprenaline than during pacing (Fig. 3, 4, and 5).

Table 4 compares the regression relations between changes in these variables and increases in heart rate. In each case, the regression slope was significantly greater for isoprenaline than for pacing-induced increases in heart rate.

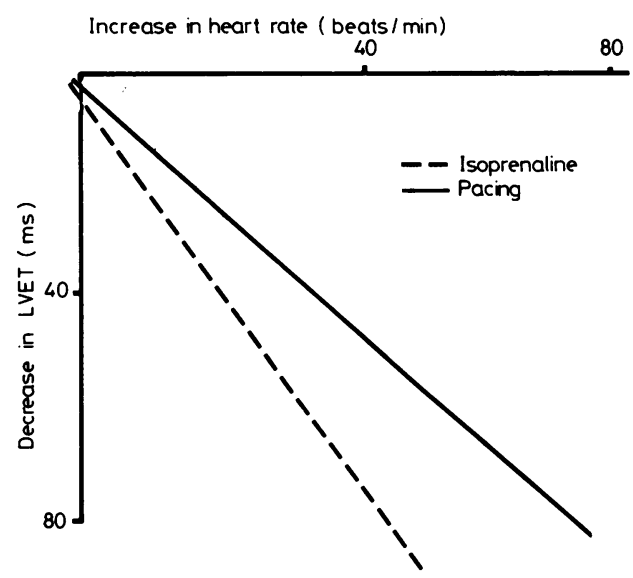

Fig. 4 Comparison of group regression lines relating decrease in LVET with increase in heart rate during atrial pacing and isoprenaline infusion. 


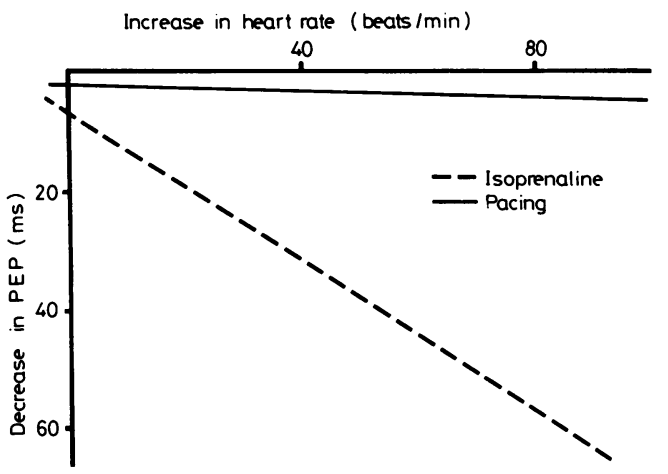

Fig. 5 Comparison of group regression lines relating decrease in $P E P$ with increase in heart rate during atrial pacing and isoprenaline infusion. The regression slope for atrial pacing does not significantly differ from zero.

Ouabain (Table 5).

Maximum increases in cardiac activity occurred between 10 to 25 minutes after the injection of ouabain. At this time there was a reduction of seven to 21 beats/min in six patients, but no change in heart rate in two. Changes in left ventricular end-diastolic pressure did not exceed $2 \mathrm{mmHg}$ in any subject. There was an average maximum increase in $\mathrm{dP} /$ $\mathrm{dt}(\max )$ and (dP/dt)/CPIP of $41 \%$ and $29 \%$, respectively. Simultaneously, reductions in left ventricular ejection time of 6 to $30 \mathrm{~ms}$ and in $\mathrm{Q}-\mathrm{S}_{2}$ of 14 to $35 \mathrm{~ms}$ were measured in six patients. In one patient left ventricular ejection time and $\mathrm{Q}-\mathrm{S}_{2}$ were unchanged and in one the relation was reversed. Reductions in pre-ejection period (0 to $14 \mathrm{~ms}$ ) were small and inconsistent.

\section{Rate-independent changes}

It was assumed that the inotropic component of an isoprenaline-induced change equalled the difference between values recorded at the same heart rate during pacing and during isoprenaline infusion. This measure was termed the rate-independent rise for $\mathrm{dP} / \mathrm{dt}(\max )$ and $(\mathrm{dP} / \mathrm{dt}) / \mathrm{CPIP}$, and the rateindependent reduction for $\mathrm{Q}_{-} \mathrm{S}_{2}$ and LVET. As the regression relation between each variable and electrically induced change in heart rate varied between individual patients, rate-independent changes were calculated separately for each patient.

For ouabain, rate-independent changes were calculated after extending the regression relation between each variable and paced heart rate to the lower heart rates recorded after ouabain.

Excellent correlations were shown within the patient group between the various rate-independent changes induced by drugs. For isoprenaline, rateindependent reduction in $\mathrm{Q}-\mathrm{S}_{2}$ correlated well with
Table 3 Effects of isoprenaline

\begin{tabular}{|c|c|c|c|c|c|c|c|}
\hline $\begin{array}{l}\text { Case } \\
\text { No. }\end{array}$ & Rate & $L V E D P$ & $\begin{array}{l}d P / \\
d t(\max )\end{array}$ & $\begin{array}{l}(d P / d t) / \\
C P I P\end{array}$ & $Q-S_{2}$ & LVET & PEP \\
\hline 1 & $\begin{array}{l}72 \\
88 \\
68 \\
89\end{array}$ & & & & $\begin{array}{l}374 \\
324 \\
330 \\
268\end{array}$ & $\begin{array}{l}263 \\
245 \\
258 \\
210\end{array}$ & $\begin{array}{r}111 \\
78 \\
72 \\
58\end{array}$ \\
\hline 2 & $\begin{array}{r}81 \\
90 \\
98 \\
106 \\
115 \\
130 \\
146\end{array}$ & $\begin{array}{r}16 \\
13 \\
13 \\
12 \\
12 \\
10 \\
9\end{array}$ & $\begin{array}{l}1271 \\
1619 \\
1872 \\
2418 \\
2535 \\
2740 \\
2876\end{array}$ & $\begin{array}{l}25 \cdot 6 \\
33 \cdot 5 \\
35 \cdot 8 \\
48 \cdot 1 \\
49 \cdot 3 \\
51 \cdot 7 \\
53 \cdot 8\end{array}$ & $\begin{array}{l}355 \\
320 \\
298 \\
263 \\
254 \\
221 \\
208\end{array}$ & $\begin{array}{l}272 \\
257 \\
249 \\
225 \\
219 \\
185 \\
179\end{array}$ & $\begin{array}{l}84 \\
63 \\
50 \\
37 \\
35 \\
36 \\
29\end{array}$ \\
\hline 3 & $\begin{array}{l}77 \\
81 \\
85 \\
86 \\
86\end{array}$ & $\begin{array}{r}15 \\
11 \\
9 \\
8 \\
8\end{array}$ & $\begin{array}{l}1100 \\
1353 \\
1640 \\
1524 \\
1968\end{array}$ & $\begin{array}{l}20 \cdot 1 \\
22 \cdot 6 \\
29 \cdot 7 \\
27 \cdot 9 \\
31 \cdot 2\end{array}$ & $\begin{array}{l}376 \\
358 \\
332 \\
317 \\
295\end{array}$ & $\begin{array}{l}290 \\
280 \\
275 \\
269 \\
254\end{array}$ & $\begin{array}{l}87 \\
78 \\
57 \\
48 \\
41\end{array}$ \\
\hline 4 & $\begin{array}{r}71 \\
80 \\
91 \\
96 \\
110 \\
114\end{array}$ & $\begin{array}{r}17 \\
14 \\
10 \\
7 \\
5 \\
5\end{array}$ & $\begin{array}{l}1243 \\
2068 \\
2863 \\
3172 \\
3628 \\
3697\end{array}$ & $\begin{array}{l}26 \cdot 5 \\
39 \cdot 1 \\
48 \cdot 2 \\
50 \cdot 5 \\
52 \cdot 9 \\
51 \cdot 7\end{array}$ & $\begin{array}{l}383 \\
334 \\
289 \\
288 \\
257 \\
255\end{array}$ & $\begin{array}{l}300 \\
270 \\
243 \\
234 \\
215 \\
205\end{array}$ & $\begin{array}{l}83 \\
64 \\
46 \\
53 \\
42 \\
50\end{array}$ \\
\hline 5 & $\begin{array}{r}77 \\
94 \\
103 \\
112 \\
121\end{array}$ & $\begin{array}{l}8 \\
6 \\
4 \\
5 \\
4\end{array}$ & $\begin{array}{r}880 \\
1026 \\
1628 \\
1972 \\
2000\end{array}$ & $\begin{array}{l}16 \cdot 0 \\
20 \cdot 0 \\
31 \cdot 4 \\
37 \cdot 2 \\
38 \cdot 3\end{array}$ & $\begin{array}{l}387 \\
347 \\
308 \\
283 \\
272\end{array}$ & $\begin{array}{l}265 \\
263 \\
222 \\
194 \\
197\end{array}$ & $\begin{array}{r}112 \\
85 \\
86 \\
90 \\
75\end{array}$ \\
\hline 6 & $\begin{array}{r}95 \\
99 \\
106 \\
112 \\
128 \\
132 \\
140\end{array}$ & $\begin{array}{r}8 \\
10 \\
6 \\
3 \\
- \\
6\end{array}$ & $\begin{array}{l}1700 \\
2203 \\
2680 \\
3305 \\
- \\
3940 \\
4604\end{array}$ & $\begin{array}{l}30 \cdot 9 \\
47 \cdot 1 \\
42 \cdot 6 \\
45 \cdot 1 \\
- \\
- \\
73 \cdot 7\end{array}$ & $\begin{array}{l}375 \\
346 \\
315 \\
301 \\
277 \\
275 \\
259\end{array}$ & $\begin{array}{l}264 \\
255 \\
237 \\
235 \\
202 \\
196 \\
188\end{array}$ & $\begin{array}{r}111 \\
91 \\
78 \\
66 \\
75 \\
79 \\
71\end{array}$ \\
\hline 7 & $\begin{array}{r}80 \\
92 \\
108 \\
110 \\
129 \\
138\end{array}$ & $\begin{array}{l}8 \\
8 \\
4 \\
3 \\
2 \\
2\end{array}$ & $\begin{array}{l}1456 \\
1598 \\
2672 \\
3414 \\
4207 \\
4405\end{array}$ & $\begin{array}{l}29 \cdot 3 \\
32 \cdot 5 \\
43 \cdot 5 \\
55 \cdot 4 \\
61 \cdot 2 \\
65 \cdot 0\end{array}$ & $\begin{array}{l}379 \\
357 \\
303 \\
283 \\
253 \\
237\end{array}$ & $\begin{array}{l}283 \\
258 \\
234 \\
222 \\
197 \\
182\end{array}$ & $\begin{array}{l}97 \\
99 \\
69 \\
61 \\
56 \\
55\end{array}$ \\
\hline 8 & $\begin{array}{r}78 \\
84 \\
98 \\
106 \\
119\end{array}$ & $\begin{array}{r}12 \\
8 \\
6 \\
6 \\
6\end{array}$ & $\begin{array}{l}1612 \\
2062 \\
2622 \\
2893 \\
4689\end{array}$ & $\begin{array}{l}32 \cdot 1 \\
38 \cdot 6 \\
50 \cdot 6 \\
57 \cdot 1 \\
71 \cdot 2\end{array}$ & $\begin{array}{l}390 \\
346 \\
313 \\
280 \\
247\end{array}$ & $\begin{array}{l}311 \\
276 \\
265 \\
236 \\
200\end{array}$ & $\begin{array}{l}79 \\
70 \\
48 \\
44 \\
48\end{array}$ \\
\hline
\end{tabular}

rate-independent rise in $\mathrm{dP} / \mathrm{dt}(\max )(\mathrm{r}=-0.68$, $\mathrm{p}<0.001)$ and in $(\mathrm{dP} / \mathrm{dt}) / \mathrm{CPIP}(\mathrm{r}=-0.75, \mathrm{p}<0.001)$, and rate-independent reduction in left ventricular ejection time was also well correlated $(r=-0.68$, $\mathrm{p}<0.001)$ for both $\mathrm{dP} / \mathrm{dt}(\max )$ and $(\mathrm{dP} / \mathrm{dt}) / \mathrm{CPIP}$. For pooled data from both isoprenaline and ouabain experiments the correlations were highly similar to the above values for isoprenaline alone. As shown in 
Table 4 Regression formulae relating change in heart rate $(x)$ with change in other variables $(y)$ in a group of eight patients

\begin{tabular}{lll}
\hline & Atrial pacing & Isoprenaline \\
\hline $\mathrm{dP} / \mathrm{dt}(\max )$ & $\mathrm{y}=250+9 \cdot 5 \mathrm{x}$ & $\mathrm{y}=247+45 \cdot 9 \mathrm{x}$ \\
$(\mathrm{dP} / \mathrm{dt} / \mathrm{CPIP}$ & $\mathrm{y}=4 \cdot 5+0 \cdot 19 \mathrm{x}$ & $\mathrm{y}=6+0 \cdot 66 \mathrm{x}$ \\
$\mathrm{QS}_{2}$ & $\mathrm{y}=-7-1 \cdot 13 \mathrm{x}$ & $\mathrm{y}=-23-2 \cdot 33 \mathrm{x}$ \\
$\mathrm{LVET}$ & $\mathrm{y}=-4-1 \cdot 12 \mathrm{x}$ & $\mathrm{y}=-7-1 \cdot 71 \mathrm{x}$ \\
PEP & $\mathrm{y}=-2-0 \cdot 02 \mathrm{x}$ & $\mathrm{y}=-6-0 \cdot 64 \mathrm{x}$ \\
\hline
\end{tabular}

Fig. 6; the true relation between rate-independent changes in $\mathrm{dP} / \mathrm{dt}(\max )$ and $\mathrm{Q}-\mathrm{S}_{2}$ appeared curvilinear over a wide range of isoprenaline induced effects. Over the smaller range of effects induced by ouabain alone, lesser degrees of correlation were observed. As illustrated in Fig. 7, there was no significant correlation between rate-independent changes in $\mathrm{Q}-\mathrm{S}_{2}$ and $\mathrm{dP} / \mathrm{dt}(\max )(\mathrm{r}=-0.34$,

Table 5 Effects of ouabain at various times (min) after injection

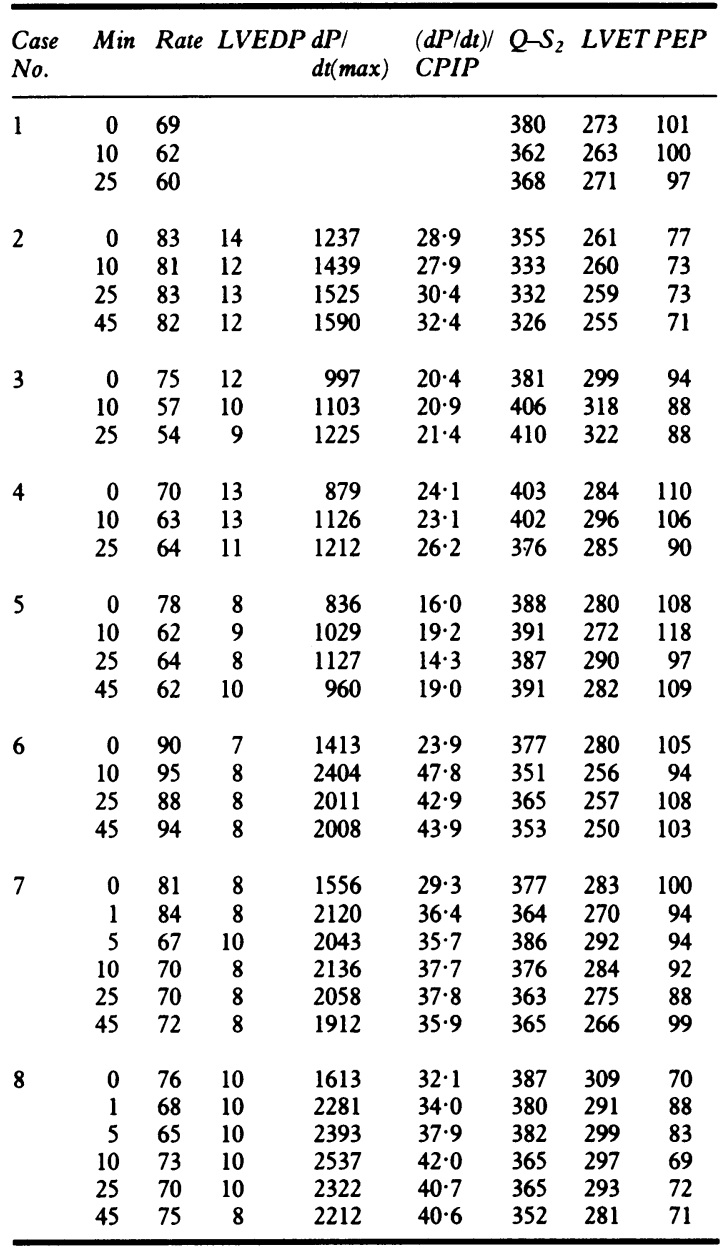

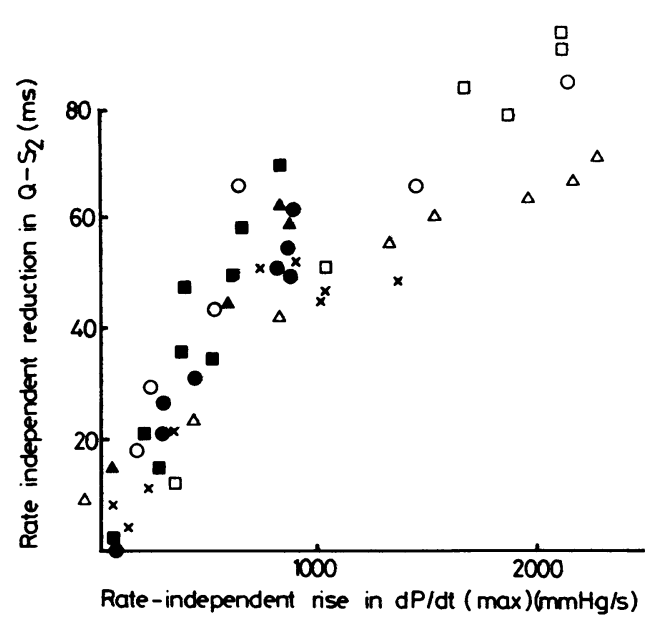

Fig. 6 The relation between rate-independent changes in $Q S_{2}$ and $d P / d t(\max )$ induced by isoprenaline. Each point represents values obtained at one infusion rate in one patient. All results from one patient are indicated by the same symbol.

p>0.05); and rate-independent reduction in left ventricular ejection time showed only a modest correlation with $\mathrm{dP} / \mathrm{dt}(\max )(\mathrm{r}=-0.44, \mathrm{p}<0.05)$. As opposed to isoprenaline effects, however, rateindependent changes in $\mathrm{dP} / \mathrm{dt}(\max )$ after ouabain were only moderately correlated with $(\mathrm{dP} / \mathrm{dt}) / \mathrm{CPIP}$ $(r=0.45, p<0.05)$, and for the latter there were better correlations $(r=0.57, p<0.01)$ with ouabain-induced rate-independent reductions in both $Q-S_{2}$ and left ventricular ejection time.

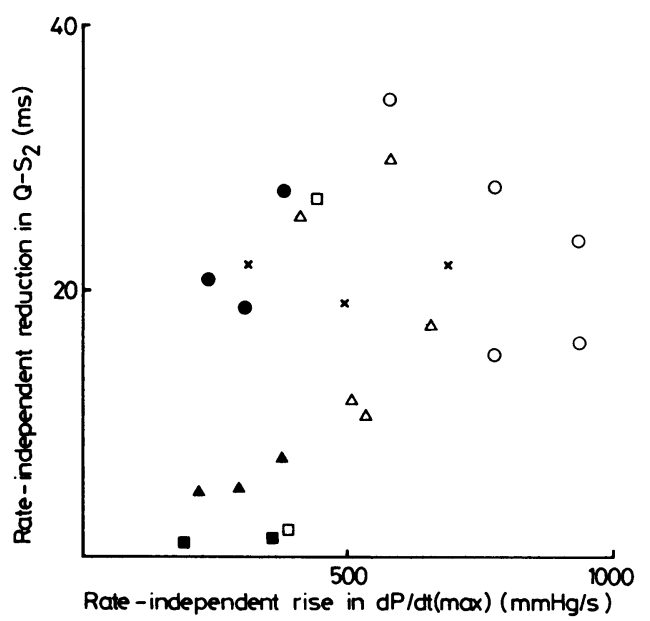

Fig. 7 The relation between rate-independent changes in $Q S_{2}$ and $d P / d t(\max )$ induced by ouabain. Each point represents values obtained at one particular time after ouabain administration, and results from one patient are indicated by the same symbol. 


\section{Discussion}

The difficulties in deriving a reliable measure of myocardial contractility in intact man have been reviewed by Mason et al. ${ }^{10}$ Though there is no completely satisfactory method, it is generally accepted that measures derived from the rate of change of intraventricular pressure correlate well with contractility under most experimental conditions. ${ }^{1-3}$ However, $\mathrm{dP} / \mathrm{dt}(\mathrm{max})$ responds not only to change in contractility, but also to alteration in either the preload or afterload of the ventricle. In the left ventricle, preload and afterload are reflected by left ventricular end-diastolic pressure and aortic mean systolic pressure, respectively. With drugs such as isoprenaline which raise aortic systolic and reduce diastolic pressure, $(\mathrm{dP} / \mathrm{dt}) / \mathrm{CPIP}$ may be a more accurate measure of contractility, as it is independent of aortic blood pressure and is also unaffected by moderate changes in left ventricular end-diastolic pressure. ${ }^{11}$ This measure must be recorded during isovolumic systole, $\mathrm{dP} / \mathrm{dt}$ being determined at any selected level of developed pressure common to control and intervention conditions. Like $\mathrm{dP} / \mathrm{dt}(\max )$ it is responsive to change in heart rate. The major limitation of either measure, however, is that they require cardiac catheterisation, and therefore cannot be used for studies of more than short duration, or in studies comparing the effects of several compounds or doses.

Determination of the duration of systole is a much more convenient procedure, is completely safe, and has been reported to provide a sensitive measure of change in cardiac performance. ${ }^{4-6}$ Externally recorded durations have been shown to be valid. The left ventricular ejection time derived externally from a carotid tracing was an accurate reflection of recordings obtained simultaneously from fluid-filled catheters in the proximal aorta, ${ }^{412} 13$ and high fidelity micromanometer tip catheterisation of the left ventricle confirmed the accuracy of the determinations of $\mathrm{Q}-\mathrm{S}_{2}$, left ventricular ejection time, and pre-ejection period derived externally. ${ }^{14}{ }^{15}$ There is evidence that certain pathological conditions specifically affect one or other phase, ${ }^{416}$ though Parker and Just ${ }^{17}$ failed to detect characteristic abnormalities even in the presence of severe derangement of ventricular performance. Like $\mathrm{dP} / \mathrm{dt}$ ( $\max$ ), systolic intervals are dependent upon alteration in preload and afterload, ${ }^{18} 19$ though the precise relation in intact man is more complex than in the isolated heart. ${ }^{20}$

$\mathrm{Q}-\mathrm{S}_{2}$, left ventricular ejection time, and preejection period have been shown to be inversely related to heart rate in a group of healthy subjects with a wide range of resting heart rates. ${ }^{921}$ The slopes of regression equations relating systolic intervals to rate in these subjects were $2 \cdot 1$ to $2 \cdot 4$ for $Q-S_{2}, 1 \cdot 7$ for left ventricular ejection time, and 0.4 for pre-ejection period. The authors have proposed that indices of systolic intervals corrected for rate according to these regression slope values are applicable measures of altered myocardial contractility. These regression slopes, however, are very similar to those derived after infusion of isoprenaline, a powerful stimulant of cardiac beta-adrenergic receptors. This suggests that the wide range of resting heart rates reported in the earlier studies was associated with individual variation in sympathetic drive. It follows that rate-corrected indices derived from such a population will correct for the total effects of altered adrenergic stimulation. Such indices are not applicable to studies of other factors changing contractility, as they consistently over-correct for heart rate increases. As would be expected, the published rate-correction indices have been reported to be insensitive measures of the inotropic effects of catecholamines. ${ }^{22}$ When in our studies heart rate was increased by electrical pacing, significantly less shortening of systole was observed than predicted from the reported regression equations. Further, only the ejection phase of systole shortened. The relations of systolic intervals to altered heart rate are very similar during electrical pacing or after atropine administration. ${ }^{23}$ Atrial pacing slightly reduces left ventricular end-diastolic pressure and also slightly increases aortic diastolic pressure, ${ }^{24}$ and it is likely that these changes have some contributory effect upon systolic intervals. It seems reasonable, however, to attribute similar responses to the specific rate-increasing component of a drug's effect. Therefore, the regression equations relating systolic intervals to paced rate change appear more applicable to studies of drug effects than those based upon a range of resting heart rates.

No correction for drug-induced change in heart rate should be applied to pre-ejection period. ${ }^{25}$ The fact that pre-ejection period appears to be rate-independent is a considerable advantage, but unfortunately this is offset by the fact that it is a small, derived variable, and is particularly prone to technical error in measurement. This may account for the insignificant reduction in pre-ejection period recorded after ouabain administration. It has been suggested that the ratio of pre-ejection period to left ventricular ejection time may be a more suitable measure of myocardial performance, ${ }^{9}$ but this ratio appeared to be highly dependent upon rate change and increased substantially during electrical pacing. The interval of longest duration, $\mathrm{Q}-\mathrm{S}_{2}$, is least affected by the technical difficulties in accurate determination, but must be corrected for change in heart rate. It is suggested that calculated rate-independent change in $\mathrm{Q}-\mathrm{S}_{2}$ is the most reliable indicator of inotropic effect. 
For the large changes produced by isoprenaline, there was an excellent inverse correlation for rateindependent changes in $\mathrm{Q}-\mathrm{S}_{2}$ and $\mathrm{dP} / \mathrm{dt}(\max )$. The non-significant correlation for ouabain represents the smaller number of experiments to some extent, but the technical imprecision in measurement is more important with a drug producing only small to moderate increase in contractility. Though systolic intervals are dependent upon preload and afterload, they correlated equally well with $\mathrm{dP} / \mathrm{dt}(\max )$ and $(\mathrm{dP} / \mathrm{dt}) / \mathrm{CPIP}$, possibly because both drugs induce a small change in preload or afterload relative to the increase in contractility. Determination of rateindependent change in $\mathrm{Q}-\mathrm{S}_{2}$ appears to be a useful indication of moderate to large inotropic change induced by any drug which does not radically alter left ventricular end-diastolic pressure or aortic blood pressure. In studies of drug-induced inotropic effect, rate-dependent change in $\mathrm{Q}-\mathrm{S}_{2}$ can be calculated by multiplying the recorded change in heart rate by the factor $1 \cdot 13$ derived from the patient group (Table 4). Rate-independent change can be derived as the difference between the observed change in $Q-S_{2}$ and the calculated rate-dependent change. It is preferable, however, that individual rate-dependence factors should be derived, as they appeared to be unique for each subject. This could be accomplished by recording $\mathrm{Q}-\mathrm{S}_{2}$ at several heart rates after administration of atropine.

These adaptations of the techniques for determination of systolic intervals may provide a precise though not highly sensitive method of assessing the effect of drugs on myocardial contractility. The techniques are convenient enough to permit repetition. The observed degree of day-to-day variation in systolic intervals, however, probably reflects variation in the degree of sympathetic drive to the heart, and suggests that measurements would be valid only if recorded during a single day.

\section{References}

1 Wiggers CJ, Stimson B. Studies on the cardiodynamic actions of drugs; mechanism of cardiac stimulation by digitalis and g-strophanthin. F Pharmacol Exp Ther 1927; 30: 251-69.

2 Gleason WL, Braunwald E. Studies on the first derivative of the ventricular pressure pulse in man. $\mathcal{F}$ Clin Invest 1962; 41: 80-91.

3 Mason DT. Usefulness and limitations of the rate of rise of intraventricular pressure (dp/dt) in the evaluation of myocardial contractility in man. Am f Cardiol 1969; 23: 516-27.

4 Weissler AM, Peeler RG, Roehll WH Jr. Relationships between left ventricular ejection time, stroke volume, and heart rate in normal individuals and patients with cardiovascular disease. Am Heart $\mathcal{f}$ 1961; 62: 367-8.

5 Weissler AM, Snyder JR, Schoenfeld CD, Cohen S. Assay of digitalis glycosides in man. Am $\mathcal{F}$ Cardiol 1966; 17: 768-80.

6 Quarry-Pigott V, Chirife R, Spodick DH. Ejection time by ear densitogram and its derivative. Circulation 1973; 48: $239-46$.

7 Medical Research Council. Responsibility in investigations on human subjects. $\mathrm{Br} M e d \mathcal{F} 1964$; ii: 178-80.

8 Ormrod R. Medical ethics. Br Med $\mathcal{J}$ 1968; ii: 7-10.

9 Weissler AM, Harris WS, Schoenfeld CD. Bedside technics for the evaluation of ventricular function in man. Am f Cardiol 1969; 23: 577-83.

10 Mason DT, Zelis R, Amsterdam EA, Massumi RA. Clinical determination of left ventricular contractility by hemodynamics and myocardial mechanics. Prog Cardiol 1972; 1: 121-53.

11 Mason DT, Braunwald E, Covell JW, Sonnenblick EH, Ross J Jr. Assessment of cardiac contractility: the relation between the rate of pressure rise and ventricular pressure during isovolumic systole. Circulation 1971; 44: 47-58.

12 Robinson B. The carotid pulse. II. Relation of external recordings to carotid, aortic and brachial pulses. $\mathrm{Br}$ Heart f 1963; 25: 61-8.

13 Benchimol A, Ellis JG. A study of the period of isovolumic relaxation in normal subjects and in patients with heart disease. Am F Cardiol 1967; 19: 196-206.

14 Bush CA, Caldwell JH, Lewis RP, Greenberger NJ, Weissler AM. Relationship of digitoxin blood level to physiologic effect in man. Circulation 1970; 42, Suppl: III-111.

15 Metzger CC, Chough CB, Kroetz FW, Leonard JJ. True isovolumic contraction time: its correlation with two external indexes of ventricular performance. $A m \mathcal{F}$ Cardiol 1970; 25: 434-42.

16 Aronow WS, Bowyer AF, Kaplan MA. External isovolumic contraction times and left ventricular ejection time/external isovolumic contraction time ratios at rest and after exercise in coronary heart disease. Circulation 1971; 43: 59-65.

17 Parker ME, Just HG. Systolic time intervals in coronary artery disease as indices of left ventricular function: fact or fancy? Br Heart $\mathcal{F}$ 1974; 36: 368-76.

18 Wallace AG, Mitchell JH, Skinner NS, Sarnoff SJ. Duration of the phases of left ventricular systole. Circ Res 1963; 12: 611-9.

19 Lance VQ, Spodick DH. Postural effects on the noninvasive baselines of ventricular performance. Cardiology 1977; 62: 296-304.

20 Shaver JA, Kroetz FW, Leonard JJ, Paley HW. The effect of steady-state increases in systemic arterial pressure on the duration of left ventricular ejection time. $\mathcal{f}$ Clin Invest 1968; 47: 217-30.

21 Weissler AM, Harris WS, Schoenfeld CD. Systolic time intervals in heart failure in man. Circulation 1968; 37: 149-59.

22 Harris WS, Schoenfeld CD, Brooks RH, Weissler AM. Effect of beta adrenergic blockade on the hemodynamic 
responses to epinephrine in man. Am $\mathcal{F}$ Cardiol 1966; 17: 484-92.

23 Harris WS, Schoenfeld CD, Weissler AM. Effects of adrenergic receptor activation and blockade on the systolic pre-ejection period, heart rate, and arterial pressure in man. $\mathcal{F}$ Clin Invest 1967; 46: 1704-14.

24 Leighton RF, Zaron SJ, Robinson JL, Weissler AM. Effects of atrial pacing on left ventricular performance in patients with heart disease. Circulation 1969; 40: 615-22.
25 Spodick DG. Measurement of cardiac pre-ejection period (letters). $N$ Engl F Med 1977; 296: 822-3.

Requests for reprints to Dr B F Johnson, Division of Clinical Pharmacology, University of Massachusetts Medical Center, Worcester, Massachusetts 01605, USA 